\title{
Developing a destination brand in the context of regional and national branding strategies: a case study of brand development of Sleman Dis- trict, Yogyakarta Special Province, Indonesia
}

\author{
Ike Janita Dewi \\ Sanata Dharma University, Yogjakarta, Indonesia
}

\begin{abstract}
Developing a destination branding is one of the popular marketing strategies employed by tourism destinations. This paper describes the process of regional brand development of Sleman District, Special Region of Yogyakarta, Indonesia. As a case study, this paper offers perspectives, strategies, and guidelines for developing a regional brand that involves relevant stakeholders. The brand development processes include stakeholders' identification, situation analysis, unique selling points identification, logo and slogan development, and brand implementation strategies. Nowadays, Indonesia has national (that is, tourism brand of Indonesia) and regional brand (that is, the brand of Special Region of Yogyakarta). In such a context, there were risks that the new brand development would conflict with the existing brands and may deliver inconsistent messages to potential visitors of the destination. Therefore, this paper recommends the development of a brand hierarchy of the national-regional-district brands to establish consistency among the brands.
\end{abstract}

Keywords: national brand, regional brand, district brand

\section{INTRODUCTION}

Branding in the context of tourism destination started to gain attention with the growing importance of tourism sector. Conceptually, the topic gained visibility with destination branding as the focal topic at the Travel and Tourism Research Association's Annual Conference in 1998 (Blain et al. 2005). The concept has been further developed and explored in a book entitled "Destination Branding" (Morgan \& Pritchard 2002). Empirically, the development of destination branding has gained popularity and become one of the most popular marketing strategies applied by both governments (national and regional) and destination management organizations.

Studies on tourism marketing in Indonesia are important to be conducted due to the importance of the sector. The number of foreign and domestic visitors visiting tourism destinations has increased yearly and reached 12 million foreign visitors in 2016 and 240 million domestic visitors in 2016 (the Indonesian Central Bureau of Statistics 2017). In terms of foreign exchange receipts, the tourism sector has been the main contributor to foreign exchange for
Indonesia. In 2014-2015, tourism sector was ranked the fourth and has significantly improved its position as the second biggest foreign exchange contributor for Indonesia in 2016 (USD 13,568 Million) after Crude Palm Oil.

To further develop the tourism sector, the Ministry of Tourism of the Republic of Indonesia has placed a great attention on marketing strategies. The formulated marketing strategies state that components of the strategies are Destination, Origin, and Time Seasonality (DOT) and Branding, Advertising, and Selling (BAS). Branding itself has gained special attention and received a much higher budget. As a result, the national tourism brand of Indonesia of 'Wonderful Indonesia' has successfully stood out in the midst of a very competitive tourism marketing in Southeast Asia (e.g. Malaysia's tourism brand of 'Malaysia Truly Asia' or Thailand's 'Amazing Thailand'). In such a national tourism marketing strategy context, a complexity raised due to the state administration system in Indonesia. Based on $\mathrm{Na}-$ tional Legislation No 34 the Year 19 on Regional Government and then revised by Legislation No 23 the Year 2014 on Regional Government (and then 
further improved by Legislation No 9 the Year 2015), Indonesia state administration system adopts the decentralization system where power resides more on the district level. Indonesia consists of 34 provinces and 514 districts.

This system has implications for the regional marketing strategy formulation, where district government also formulates their own strategy, including its destination branding strategy. Within this context, this paper described a district brand development process in Sleman district. This district is part of Yogyakarta Special Region, one of the 34 provinces in Indonesia which is renowned as Indonesia's 2nd most visited destination after Bali. Yogyakarta Special Region (or popularly called 'Jogja') itself has developed its regional brand of 'Jogja Istimewa' (or 'The Distinctively Jogja'). The case study of a district brand development process in Sleman district shows that nowadays, Indonesia has national (that is, tourism brand of Indonesia) and regional brand (that is, the brand of Special Region of Yogyakarta).

\section{LITERATURE REVIEW}

\subsection{Destination Branding}

Geographic locations, like organizations or products, can also be branded. The goal of such branding is to make people aware of the location and then link desirable associations to create a favorable image for entire visits and businesses (Keller 2003). Empirical research has demonstrated that branding enhances destination image among visitors and assists regional governments or Destination Management Organizations (DMOs) in measuring achievements. Destination branding successes, such as New Zealand's ' $100 \%$ Pure New Zealand', Singapore's 'Yours Singapore' or Amsterdam's 'I Amsterdam' have demonstrated how branding can be a positive force for nations or regions to develop their destination brands.

Fan (2005) warned that the dangers of treating place branding like commercial brands as there are fundamental differences between the two. For example, while products can be altered, re-launched, replaced or withdrawn from the market, places cannot. A nation brand can only create emotional benefits due to intangibility. Moreover, product's brands have a single owner with legal rights, whereas a place is owned by any organization (or even people or residents of a place) that chooses to exploit the image of the place. Therefore, the audiences for destination brands are diverse and hard to find, unlike product's brands that have targeted segment.
The diverse audiences of destination branding include the residents of the destination itself. This implies on the strategic importance of internal branding. In a destination brand development, residents of the place are the first audience of the brand, followed by the external audience, that is, the potential tourists to visit the destination. A destination brand's promise is mainly fulfilled by the residents of the destination by offering best hospitality to visitors. Therefore, with regards to the strategic importance of internal branding, the definition of destination branding is as follows. Destination branding is the set of marketing activities that (1) support the creation of a name, symbol, logo, word mark or other graphics that readily identifies and differentiates a destination; (2) consistently convey the expectation of a memorable travel experience that is uniquely associated with the destination; (3) serve to consolidate and reinforce the emotional connection between the visitor and the destination; (4) reduce consumer search costs and perceived risk; and (5) serve to coordinate and build commitment to the internal stakeholder to deliver quality brand experience. Collectively, these activities serve to create a destination image and brand experience that positively influences consumer destination choice (Blain et al. 2005, Dewi 2009).

Internal branding can be started with the formulation of the brand identity of the destination and then communicate it to the society. The brand identity of a destination is the attributes and characters of a destination from the perspective of its internal stakeholders (Burmann \& Zeplin 2005). Buckley (2005) and Burmann \& Zeplin (2005) stated that identity precedes image meaning that a solid brand identity should be first constructed before communicated to its external consumers.

Furthermore, the intense competition in the tourism sector also provides reasons why image and branding have been very important to tourism destinations. Baker \& Cameron (2008) argue that the main reasons for destination branding growth are related to either competition issues or consumer behavior. Substitutability has become one of the main problems for destinations today. In addition, most destinations have excellent facilities and services and claim to have unique culture and heritage (Morgan \& Pritchard 2002). Also, tourists are becoming increasingly sophisticated and discerning and destination choice is now becoming a considerable indication of lifestyle and a way to express identity in an increasingly homogenous world (Morgan \& Pritchard 2002).

Clarke (2000) states that relevance of branding to tourism destinations (as a part of marketing strategies) can be summarized into the following 6 (six) 
points: (1) Tourism involves complex and high involvement purchase decisions, thus, branding can reduce the choices available for consumers, (2) Branding can help reduce some of the intangibility of tourism products, especially if combined with positive past experience, (3) Branding can communicate a sense of consistency of image especially for tourism sector which involves many parties (travel agents, tour operators, restaurants, hotels, attractions, transportations, tourist guides, and so on), which make it sensitive to variability of experience, (4) Branding can act as a mechanism to reduce the risk of ill-spent time through selection of a poor destination, (5) Given the inseparable nature of tourism product and the desire for segment compatibility, therefore, being high, branding helps ensure tourist satisfaction and thus facilitates precise segmentation, and (6) In such a high-context service, motivation and teamwork are a high priority as tourism and brands can provide a focus for the integration of producer effort and assist people in working towards the same outcome (i.e. a brand can serve as a contract of quality between producer(s) and their customer(s) therefore motivate the producers to fulfill what the brand promises). Therefore, the need for destination branding is relevant to the tourists' point of view. The development of a unique, effective branding campaign can, therefore, differentiate a destination from the competitor.

\subsection{Destination Brand Building}

Destination/place branding performs four main functions (Blain et al. 2005), namely: (1) brands as communicators, where brands "represent a mark of ownership and a means of product differentiation manifested in legally protected names, logos, and trademarks", (2) brands as perceptual entities which appeal to consumer senses, reasons, and emotions, (3) "brands as values enhancers" which led to the concept of brand equity, and (4) "brand as relationships" where the brand is construed as having a personality which enables it to form a relationship with the consumers. Based on those propositions, the destination/place branding is constructed as "relational brand network" which includes the core brand and four categories of brand relationships that are, consumer relationships, brand infrastructure relationships, primary service relationships, and media relationships. This perspective is taken by the author as the main framework for developing the brand of Sleman district.

\section{RESEARCH METHODS}

The brand development process for Sleman District followed Hankinson's conceptual framework of destination brand building which was built around the concept of a brand networks (Blain et al. 2005). The procedure also adopts the perspective of Burmann \& Zeplin (2005) on the formulation of the brand identity of the destination. For that purposes, a series of data collection was conducted with the following groups. (1) Discussion with stakeholders. The key stakeholders identified were Sleman Tourism Office, Regional Development Planning Board, Culture Office, the tourism industry stakeholders (tour operators, hotels and restaurants, and tour guides), and the media. (2). Expert interview. The experts involved in the process were researchers, academics, and design expert. (3). Tourist behavior analysis. The analysis included survey and interviews with tourists visiting tourist destinations in Sleman. Majority of the tourists interviewed were foreign tourists to gain international market's perspectives about Sleman.

Table 1. Destination Brand Development Phases

\begin{tabular}{|c|c|c|}
\hline Phase & $\begin{array}{l}\text { Description of } \\
\text { Activities }\end{array}$ & Outcome (Data or Activities) \\
\hline $\begin{array}{c}\text { Phase } \\
1\end{array}$ & $\begin{array}{l}\text { Stakeholder } \\
\text { identification } \\
\text { Market Analysis } \\
\text { and Competitor } \\
\text { Analysis }\end{array}$ & $\begin{array}{l}\text { List of internal and external } \\
\text { stakeholders } \\
\text { Tourist products, number of } \\
\text { visitors, visitors trend, market } \\
\text { demand, competition analysis }\end{array}$ \\
\hline $\begin{array}{l}\text { Phase } \\
2\end{array}$ & $\begin{array}{l}\text { Core Brand de- } \\
\text { velopment } \\
\text { Brand Identity } \\
\text { development }\end{array}$ & $\begin{array}{l}\text { Formulation of brand identity } \\
\text { Identification of strong and } \\
\text { unique icons of values of the } \\
\text { destination (cultural values, } \\
\text { heritage, culinary, perfor- } \\
\text { mances, etc) }\end{array}$ \\
\hline $\begin{array}{c}\text { Phase } \\
3\end{array}$ & $\begin{array}{l}\text { Brand element } \\
\text { development }\end{array}$ & Logo, Slogan, and Tagline \\
\hline $\begin{array}{c}\text { Phase } \\
4\end{array}$ & $\begin{array}{l}\text { Brand Launch } \\
\text { and Implemen- } \\
\text { tation }\end{array}$ & $\begin{array}{l}\text { Brand introduction and so- } \\
\text { cialization to general public } \\
\text { and tourism stakeholders } \\
\text { Gaining commitment (inter- } \\
\text { nal branding) } \\
\text { Formulation of marketing } \\
\text { strategies to build brand equi- } \\
\text { ty } \\
\text { Formulation of relationship } \\
\text { infrastructure to build brand } \\
\text { equity (consumer, brand in- } \\
\text { frastructure, media, tourism } \\
\text { service relationships) }\end{array}$ \\
\hline $\begin{array}{l}\text { Phase } \\
5\end{array}$ & $\begin{array}{l}\text { Development of } \\
\text { Monitoring and } \\
\text { Evaluation Plan }\end{array}$ & $\begin{array}{l}\text { Time schedule, parameter, } \\
\text { development of methods and } \\
\text { tools to gain feedback from } \\
\text { stakeholders. }\end{array}$ \\
\hline
\end{tabular}


The brand development involved 5 (five) phases of: (1) Stakeholder Identification, market analysis, and competitor analysis, (2) Core brand development and brand identity development, (3) Brand element development, (4) Brand launch, and (5) Development of Monitoring and Evaluation Plan. The phases, description of activities, and outcome of each phase are described in the Table 1.

\section{CHALLENGES IN REGIONAL BRAND DEVELOPMENT}

The challenge in regional brand development in Indonesia lies on the state administration system in Indonesia where authority resides more on the district level. The central government systematic involvement in the brand development both at the national level and at regional level began with the development of Branding-Advertising-Selling marketing strategies by the Ministry of Tourism of the Republic of Indonesia. The strategy resulted in the decision of establishment of Wonderful Indonesia as the master brand for Indonesia tourism. Therefore, the development of destination brands in Indonesia must adhere to the guidelines (both technical and conceptual) of Wonderful Indonesia brand. However, before such branding strategy was widely communicated to provinces and districts in Indonesia, at the provincial levels, some provinces have already developed their own regional brands. With the status of Yogyakarta Special Region as a special province and a renowned tourist destination, the need of developing its brand has emerged quite a while before the systematic destination brand strategy was adopted by Ministry of Tourism at the national level. As a result, there has been the brand of Jogja Istimewa as the brand of Yogyakarta Special Region which is supposed to act as a master brand for the districts (including Sleman District) as parts of the province.

The complexity arose in 2016 as the Ministry of Tourism also developed and launched the destination brand which encompasses two provinces (that is, Yogyakarta Special Region and Central Java province). These two provinces were regarded as 'one destination' in the perspective of the national tourism development master plan. As a derivative of the national brand of 'Wonderful Indonesia', the brand of Yogyakarta Special Region and Central Java Province was developed applying the guidelines of 'Wonderful Indonesia' brand Therefore, the brand of "Java: Cultural Wonders" also existed. Sleman district as a part of Yogyakarta Special Region also belongs to this destination and will be marketed using this brand as well.

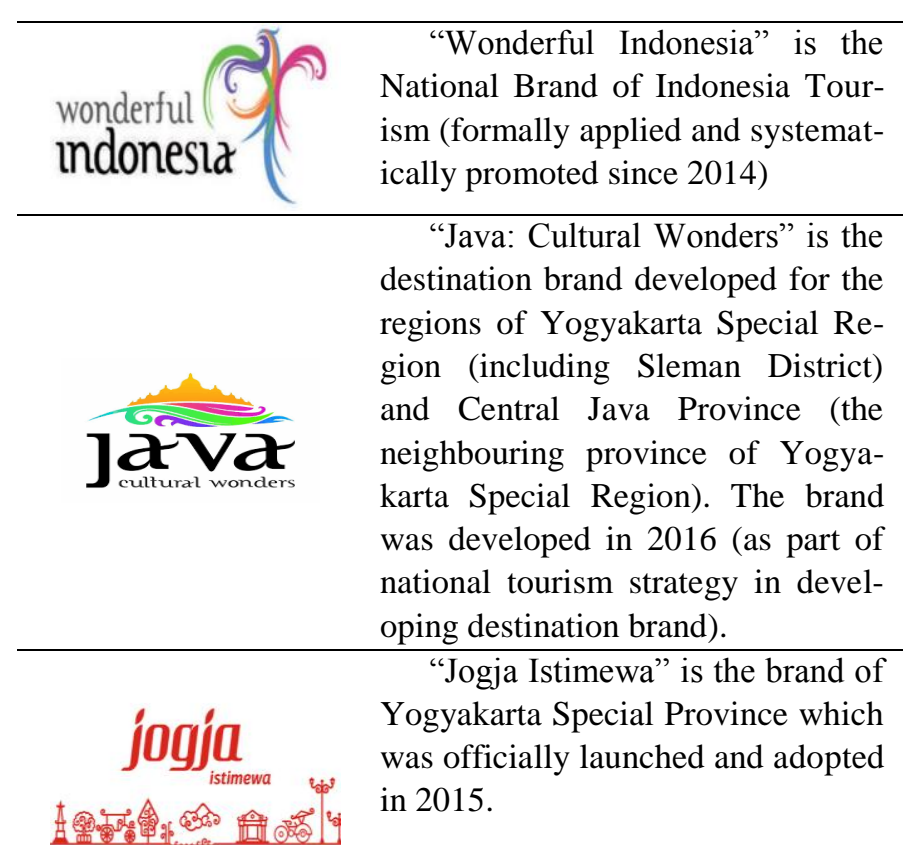

Figure 1. The National and Regional Brands Already Existed before the Development of Sleman District Brand

In such a context, the development of a brand of Sleman had to comply and consistent with the master brand.

\section{CONCLUSION}

The brand development process in Sleman has finally completed the executive decision that the brand of Sleman District should comply and be consistent with the brand of Yogyakarta Special Province. The choice was made based on the consideration that Sleman district is directly associated with Yogyakarta Special Province. The image of 'Jogja' has been shared inseparability with the image of Sleman. However, this decision was taken at the expense of inconsistency between the district and the national brand. As the case study of Sleman can occur at other destination brand development in Indonesia, brand architecture or brand hierarchy is definitely needed to develop. Perhaps, the central government (i.e. Ministry of Tourism should be responsible for this task). Finally, the brand of Sleman was decided as follows:

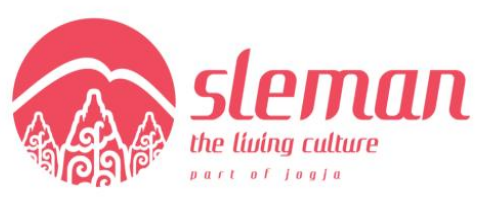

Figure 2. The Destination Brand of Sleman District 
Sleman is the brand name. It states the identity of region. Prambanan Temple and Mount Merapi are the logo. These represent the iconic assets of Sleman as the flagship products.

The Living Culture is the tagline. . It states that the core element and culture is a differentiating element of Sleman. The living culture means the dynamic culture of Sleman, which signifies that the traditional culture and traditions evolve in harmony with the modern/contemporary culture. Living culture also means that people of Sleman strive for the values of hospitality, open-mindedness, creative, and multicultural. These values represent the characteristics of Sleman which also a host of nationally and internationally renowned universities and tertiary education institutions.

It means that Sleman District will create synergy with Yogyakarta Special Province in developing the region and the society. Culture is chosen as the spirit of development.

The font type chosen is lowercase, representing the spririt of egalitarianism. The font used is modeled after the Javanese characters. The color identity is red, which represents the color identity of the Royal Palace of Ngayogyakarta Hadiningrat.

\section{REFERENCES}

Baker , M. J. \& Cameron, E. 2008. Critical success factors in destination marketing. Tourism \& Hospitality Research 8(2): 79-97.

Blain, C., Levy, S.E., \& Ricthie, J.R.B. 2005. Destination Branding: Insights and Practices from Destination Management Organizations. Journal of Travel Research 43(May): 328-338.

Buckley. 2005. Internal Branding. New Jersey: John Wiley and Sons.

Burmann, C. \& Zeplin, S. 2005. Building Brand Commitment: A Behavioral Approach to Internal Brand Management. Brand Management 12(4): 279-300.

Clarke. J. 2000. Tourism Brands: An Exploratory Study of the Brands Box Model. Journal of Vacation Marketing 6(4): 329-345.

Central Bureau of Statistics. 2017 August 2. Foreign Exchange Receipts. Retrieved from http://www.bps.go.id.

Dewi, I.J. 2009. Creating and Sustaining Brand Equity, Yogyakarta: Amara Books.

Fan, Y. 2005. Branding the Nation: What is Being Branded. Journal of Vacation Marketing 12(1): 5-14.

Keller, K.L. 2003. Strategic Brand Management: Building, Measuring, and Managing Brand Equity, $2^{\text {nd }}$ Edition, New Jersey: Pearson Education.

Ministry of Tourism Republic of Indonesia. 2017. "Indonesia Tourism Outlook 2018, presentation of Minister of Tourism Republic Indonesia, Jakarta: 1 November.

Morgan, N. \& Pritchard, A. 2002. Contextualizing Destination Branding. Destination Branding: Creating the Unique Destination Proposition. Oxford: Butterworth-Heinemann. 